\title{
Comprehensive Ecological Management of Black and Smelly Open Channels: Evidence from Wuhan, China
}

\author{
Fang $\mathrm{He}^{1 *}$, Jian Wang ${ }^{1}$, Xiaojun Chen ${ }^{2}$ \\ ${ }^{1}$ School of Urban Construction, Wuhan University of Science and Technology, Wuhan 430065, China \\ ${ }^{2}$ YCIH No. 2 Water Resources and Hydropower Construction Co., Ltd, Kunming 650501, China
}

Corresponding Author Email: hefang@wust.edu.cn

\section{https://doi.org/10.18280/ijdne.150303}

Received: 10 January 2020

Accepted: 30 March 2020

\section{Keywords:}

black and smelly open channels, aeration, biological floating islands, comprehensive ecological management

\begin{abstract}
Despite successful initial treatment, many black and smelly waterbodies in China are polluted again, returning to the black and smelly state. To realize long-term control of water quality, this paper puts forward an integrated bioremediation method for black and smelly waterbodies, coupling nano-aeration instruments, ecological stimulators, online microbial reactors, and biological floating islands. The proposed method was applied to treat a black and smelly open channel in Central China's Wuhan City, which returned to the black and smelly state after successful initial treatment. The results show that our method reduced chemical oxygen demand (COD), ammonia nitrogen (NH3-N), and total phosphorous (TP) by $31 \%, 60 \%$, and $55 \%$, respectively, and improved transparency and dissolved oxygen (DO) by $55 \%$, and $180 \%$, respectively. The water quality of the open channel was significantly improved, the smell and eutrophication were eliminated as desired, and the water quality indices all reached level V in the Environmental Quality Standards for Surface Water (GB3838-2002). To sum up, our method could gradually restore the ecology and degradation ability of rivers, kicking off a vicious cycle of the ecosystem in waterbodies.
\end{abstract}

\section{INTRODUCTION}

As economy and urbanization pick up speed, many urban rivers have suffered from serious pollution and biodegradation [1-3], as evidenced by the stubbornly high levels of oxygenconsuming organic pollutants, and nitrogen and phosphorus nutrients [4-6]. In severe cases, the waterbodies become black and smelly seasonally or perennially $[7,8]$. As a result, many Chinese cities have prioritized the treatment of black and smelly waterbodies.

According to the "National Urban Black and Smelly Water Treatment Supervision Platform”, as of the end of 2019, China has identified a total of 2,869 black and smelly waterbodies, of which 2,313 have been treated and 556 are under treatment [9]. Overall, the black and smelly waterbodies have been treated well, for the treated water meets the requirements on normal use.

However, the treatment effect is not so optimistic as revealed by follow-up surveys on the completed treatment projects of black and smelly waterbodies. Despite the initial results, most treated waterbodies are polluted again [10-12], returning to the black and smelly state $[13,14]$. This is because the preliminary investigation is insufficient, and the technical solutions lack pertinence and continuity. As the waterbodies become black and smelly again, lots of manpower and materials are needed for repeated treatment [15]. This calls for a purification technique with a wide applicable scope and good lasting effect [16, 17].

There are many techniques to treat black and smelly rivers, including chemical methods, physical methods, bioremediation methods, and other new methods. The chemical methods aim to speed up water purification by throwing chemicals into the river, namely, flocculants and precipitants [18]. These methods can improve river water quality in the short term $[19,20]$, but the chemical reagents have an impact on the eco-environment, plants, and animals in the river [21, 22].

The physical methods mainly include artificial aeration [23], sediment dredging [24], water diversion and flushing [25-27], and mechanical algae removal [28]. For example, Liu et al. [29] prepared oxygen-containing natural porous materials through vacuum degassing, and covered them on anaerobic sediment to continuously adjust the dissolved oxygen (DO) in black and smelly waterbodies. Zhu et al. [23] achieved excellent treatment effect through continuous aeration with microporous air diffusers: the thickness of bottom sediments was reduced from $0.9 \mathrm{~m}$ to $0.6 \mathrm{~m}$. However, aeration is usually combined with ecological purification [30]. Pan et al. [31] proved that aeration, coupled with biofilms, can effectively remove the nitrogen in polluted rivers.

Through top-level design and ecological planning of water treatment projects, the bioremediation methods respect the natural ecological laws of the river system, and rely on the selfcleaning capacity of the ecosystem to eliminate pollutants [3234]. For instance, Yuan et al. [7] compared the potentials of three bioremediation methods (i.e. aeration, bio-stimulation, and bioaugmentation) in pollutant removal of urban waterbodies, revealing that aeration and bioaugmentation greatly suppressed chemical oxygen demand (COD) but hardly reduced the nitrogen level. Liu et al. [29] found that the hybrid of bioaugmentation with aeration could reduce COD, ammonia nitrogen $\left(\mathrm{NH}_{3}-\mathrm{N}\right)$, and total nitrogen $(\mathrm{TN})$ by $53.4 \%$, 
$85.0 \%$, and $24.9 \%$, respectively. Through bio-stimulation, AlMailem et al. [35], Simpanen et al. [36] added nutrients to promote the proliferation of indigenous microorganism, and demonstrated that the potential of bacterial degradation increases with the addition of carbon, nitrogen, and vitamin.

The other new treatment methods for black and smelly waterbodies include ecological riverbanks, purification lakes, and biofilms [37]. To improve the water quality of the Yangjiang River, Chen et al. [38] created an ecological, permeable pond system and a similar wetland system; the removal efficiencies of COD, total phosphorous (TP), TN, $\mathrm{NH}_{3}-\mathrm{N}$, and suspended solids (SS) were $16.7 \%, 29.58 \%$, $21.63 \%, 20.0 \%$, and $99.8 \%$, respectively, for the pond system, and $44.0 \%, 17.1 \%, 6.7 \%, 13.9 \%$, and $80.0 \%$, respectively, for the wetland system. De Matos et al. [39] constructed a wetland with horizontal subsurface flow, which reduced the main pollutant levels (e.g. COD, TN, and TP) in the river channel below those specified in national standards. Lv et al. [40] analyzed the startup modes, optimal parameters, formation, and replacement of biofilms, and suggested the strong potential of the biofilm technique in in-situ remediation of polluted water.

In recent years, many scholars have applied ecological floating islands or constructed wetlands to treat polluted waterbodies [41, 42]. Masi et al. [43] adopted constructed wetlands to treat overflow sewage in Italy, and successfully removed $90 \%$ of COD at a low cost. Ávila et al. [44] designed a constructed wetland with horizontal flow and vertical flow in series; the wetland was found to excel in sewage treatment, but the removal rate varies from summer to winter. To improve this constructed wetland, Nguyen et al. [45] introduced expansive clay (ExC) as the cushion of the wetland, and planted Colocasia esculenta and Dracaena sanderiana on the wetland; the improved wetland achieved an obvious effect in pollutant removal. Using Pontederia sagittata and Cyperus papyrus, Olguín et al. [46] developed floating treatment wetlands (FTWs) to improve the water quality of eutrophic waterbodies; experimental results show that the DO increased by $15-67 \%$, fecal coliform removal rate fell in $9-86 \%$, nitrate removal rate was $9-76 \%$, but the total Kjeldahl nitrogen (TKN) remained relatively high. Saggaï et al. [47] probed deep into the plants on ecological floating islands, and learned that monocotyledonous plants with $\mathrm{C} 4$ or C4-type photosynthetic pathways can survive better and effectively remove pollutants: the removal rates of biological chemical demand (BOD), COD, total suspended solids (TSS), TP, $\mathrm{NH}_{3}-\mathrm{N}$, and nitrate are $90 \%$, $80 \%, 94 \%, 60 \%$, and 50\%, respectively. Panfili et al. [48] proved that the addition of safeners enables aquatic floating plants to remove pollutants more effectively.

Despite their long operating period, bioremediation methods can fundamentally improve the water environment of the river at a low operating cost. The treatment technique could be integrated with the water landscape, and beautify the river landscape, while improving water quality. If properly managed, bioremediation methods can ensure the long-term quality of river water [49]. For example, Nanjing City performed bioremediation of the Nonghua River: aquatic plants were placed in the shallow area to adsorb water pollutants like nitrogen and phosphorous; the DO in water was increased rapidly through fountain aeration [50]. Kunshan City effectively treated polluted waterbodies through the following measures: cutting off pollution sources, dredging, adding microbial bacteria, planting aquatic plants, and setting ecological buffer zones [51]. Changzhou treated the Zaogang
River with an integrated system of bottom laminar flow aeration, bio-enhanced degradation, and ecological floating islands, and removed an average of $84.4 \%, 98.6 \%$ and $65.3 \%$ of $\mathrm{TP}, \mathrm{NH}_{3}-\mathrm{N}$, and $\mathrm{COD}$, respectively [52]; the treated water surpassed level IV in the Environmental Quality Standards for Surface Water (GB3838-2002).

To sum up, if bioremediation methods are selected to treat black and smelly waterbodies, it is necessary to construct a reasonable ecosystem based on the pollution degree, local climate, and plant growth, and supplement bioremediation with proper management.

In this paper, a black and smelly open channel in Central China's Wuhan City is selected as the object. The open channel had been treated before, but was polluted again, returning to the black and smelly state. Multiple techniques, namely, nano-aeration, microbial enhanced degradation, ecological floating island, were integrated to treat this open channel. Besides, an aquatic plant system was constructed to enhance the self-cleaning capacity of the river, aiming to fundamentally enhance the river's resistance to pollutant impact.

The remainder of this paper is organized as follows: Section 2 introduces the basic information and previous treatment of the black and smelly open channel; Section 3 details the integrated remediation method for the polluted waterbody; Section 4 applies the proposed method to the open channel, and analyzes the one-year monitoring data on water quality, proving the effectiveness of our method; Section 5 puts forward the conclusions.

\section{BACKGROUND INFORMATION}

\subsection{Basic information}

The open channel is a $2.13 \mathrm{~km}$-long east-west truck drainage channel in Wuhan City. It mainly collects rainwater along the route and the upstream water from box culverts. The crosssectional dimensions are: base length $\mathrm{B}=3 \mathrm{~m}$, height $\mathrm{H}=3 \mathrm{~m}$, and slope coefficient $\mathrm{m}=2$. The catchment area was planned to be $3.39 \mathrm{~km}^{2}$.

Currently, the open channel is surrounded by residential communities, factories, and enterprises. There is a total of 25 drainage outlets along the route, including 18 for rainwater, and 7 for mixed-flow. The nearby region is crisscrossed by numerous small rivers. In flood season, the water level of the river outside the embankment is generally above the ground within. The water stagnant in the embankment needs to be drained by pumping stations.

The open channel is designed as a main channel for rainwater discharge. Ecological landscape is another important function of the channel. Relevant documents require the water quality in the open channel to reach the standard for level V surface water in 2030.

\subsection{Pollution causes}

\subsubsection{Point source pollution}

The sewage pipelines in the nearby region have been completed. But the pipelines of some residential communities are connected incorrectly. Some wastewater is discharged to the open channel via rainwater pipelines. Most factories, enterprises, and institutions in this region discharge rainwater and wastewater together. Some of them discharge rainwater 
and wastewater separately. However, the wastewater still enters the open channel, due to the incorrect connections of the pipelines.

\subsubsection{Non-point source pollution}

The initial rainwater is easily polluted due to the lack of sponge city facilities, the intensive development of nearby land, and the limited waterbody capacity.

\subsubsection{Internal pollution}

In the water of the open channel, black and smelly bottom mud has formed from floating matters, suspended matters, shore garbage, fallen leaves, and uncleaned aquatic plants. The pollutants released from the bottom mud make the water black and smelly, causing the open channel to lose self-cleaning capacity.

What is worse, rainwater and wastewater are discharged together in some areas of the upstream. On sunny days, the wastewater flows into rainwater box culverts. The large crosssection, coupled with the small and slow flow of wastewater, adds to the probability of siltation. On rainy days, the silts in the box culverts are carried by storm water into the open channel, increasing the internal pollution.

\subsubsection{No fresh water supply}

The open channel is responsible for discharging the rainwater within the basin. However, there is no safe, clean, and reliable water supply on sunny days. Hence, the water in the channel is poor in mobility and self-cleaning ability, and prone to eutrophication. As a result, the open channel is easily polluted, becoming black and smelly.

\subsection{Water quality monitoring data}

Previously, the open channel was treated by installing sewage interception pipes, repairing slopes, and dredging bottom mud. These treatments have greatly improved the water quality in the channel. But the water in the channel is still slightly black and smelly. The water quality of the open channel was monitored at points in the upper, middle, and lower parts [53, 54]. The monitoring data are listed in Table 1 below.

Table 1. Water quality monitoring data

\begin{tabular}{|c|c|c|c|c|c|c|}
\hline \multirow{2}{*}{ Items } & \multicolumn{4}{|c|}{ Sampling points } & \multirow{2}{*}{ Analysis methods } & \multirow{2}{*}{ Instruments } \\
\hline & Upper part & Middle part & Lower part & Average & & \\
\hline Transparency & 25 & 22 & 20 & 22.33 & Secchi disc method & Secchi disc \\
\hline DO & 2.1 & 1.8 & 1.5 & 1.8 & $\begin{array}{l}\text { Electrochemical probe } \\
\text { method }\end{array}$ & $\begin{array}{c}\text { JPB-607A Portable dissolved } \\
\text { oxygen analyzer }\end{array}$ \\
\hline COD & 28.18 & 28.74 & 30.02 & 28.98 & $\begin{array}{l}\text { Fast digestion } \\
\text { spectrophotometry }\end{array}$ & $\begin{array}{l}\text { EFC-3B Portable COD fast } \\
\text { measuring instrument }\end{array}$ \\
\hline $\mathrm{NH}_{3}-\mathrm{N}$ & 4.97 & 5.01 & 5.27 & 5.08 & $\begin{array}{l}\text { Nessler's reagent } \\
\text { spectrophotometry }\end{array}$ & $\begin{array}{l}\text { SP-721 (E) Visible } \\
\text { spectrophotometer }\end{array}$ \\
\hline TP & 0.48 & 0.42 & 0.42 & 0.44 & $\begin{array}{l}\text { Ammonium molybdate } \\
\text { spectrophotometry }\end{array}$ & $\begin{array}{l}\text { SP-721 (E) Visible } \\
\text { spectrophotometer }\end{array}$ \\
\hline
\end{tabular}

As shown in Table 1, the water quality of the open channel falls short of level V in GB3838-2002. The waterbody is slightly black and smelly, according to the Grading Standard for Pollution Degree of Urban Black and Smelly Waterbodies in the Guide for Treatment of Urban Black and Smelly Waterbodies.

\subsection{Treatment goal}

The black and smelly state and eutrophication of the waterbody should be eliminated, and the water quality indices should meet the standard for level V surface water.

\section{METHODOLOGY}

This paper aims to fundamentally enhance the river's resistance to pollutant impact, improve the landscape effect, and realize long-term management. Considering the current situation and functional positioning of the open channel, an insitu purification and bioremediation strategy was designed to treat the water in the open channel naturally, with proper artificial intervention. Our strategy integrates techniques like nano-aeration, microbial enhanced degradation, and ecological floating island. The aquatic ecosystem in the channel was built up gradually, and an aquatic plant system was also constructed to enhance the self-cleaning capacity of the channel.

\subsection{Nano-aeration}

Nano-aeration oxygenates the waterbody by nano-aeration instruments, that is, elevates the DO level in water. With the circulating water flow, the oxygen-rich water is brought to all corners of the river, turning the entire river into an aerobic environment. In this way, the water body will no longer give off an unpleasant smell, owing to the lack of oxygen, and the aquatic environment will enjoy sufficient supply of DO. The aerobic microorganisms will be revived and activated.

In the waterbody of the open channel, the oxygen demand consists of two parts: physical oxygen demand $\left(\mathrm{O}_{\mathrm{p}}\right)$ and microbial oxygen demand $\left(\mathrm{O}_{\mathrm{m}}\right)$. The former refers to the amount of oxygen required to directly increase the water content from the current DO to the target DO, while the latter refers to the amount of oxygen consumed by microbial decomposition of organic matters. The two oxygen demands can be respectively calculated by:

$$
O_{p}=\left(D O_{\text {target }}-D O_{\text {current }}\right) V / t
$$

where, $O_{p}$ is physical oxygen demand $(\mathrm{kg} / \mathrm{h}) ; D O_{\text {target }}$ is the target DO $(\mathrm{mg} / \mathrm{L}) ; D O_{\text {current }}$ is the current DO $(\mathrm{mg} / \mathrm{L}) ; V$ is the water storage $\left(\mathrm{m}^{3}\right) ; t$ is the required reoxygenation time $(\mathrm{h})$.

$$
O_{m}=\left(C_{0-B O D}-C_{s-B O D}\right) V K_{B O D} / t
$$


where, $O_{m}$ is microbial oxygen demand $(\mathrm{kg} / \mathrm{h}) ; C_{O-B O D}$ is the target biochemical oxygen demand $\left(\mathrm{BOD}_{5}\right)(\mathrm{mg} / \mathrm{L}) ; C_{s-B O D}$ is the current $\mathrm{BOD}_{5}(\mathrm{mg} / \mathrm{L}) ; K_{B O D}$ is biological aerobic load $\left(\mathrm{kgO}_{2} / \mathrm{kgBOD}_{5}\right) ; \mathrm{t}$ is the required reoxygenation time (h).

The number of aeration instruments can be determined by:

$$
\mathrm{L}=\frac{O_{p}+O_{m}}{B \eta} k
$$

where, $L$ is the number of aeration instruments (each); $B$ is the oxygenation capacity per instrument $(\mathrm{kg} / \mathrm{h}) ; \eta$ is oxygen utilization rate; $k$ is the safety factor.

In the light of the current situation and treatment goals of the open channel, 120 aeration instruments are needed to satisfy the oxygen demand $(10.8 \mathrm{~kg} / \mathrm{h})$.

\subsection{Bioremediation}

Two ecological stimulators and two online microbial reactors were deployed along the linear open channel. In each ecological stimulator, eco-remediation agent was placed in a semi-closed environment, creating an environment-friendly in-situ activation platform. Then, the water flow could circulate automatically from the external environment to the reaction tank, and back to the external environment. Through the circulation, the environment-friendly in-situ microorganisms in the water body were transported to the ecological stimulator for activation and proliferation. Then, the proliferated microorganisms were released back into the water body. With the ecological simulators, the nitrogen in the open channel could be fully degraded from organic nitrogen, ammonia nitrogen, nitrate nitrogen, to nitrogen gas. In this way, nitrogen was transformed from the ionic state to the gaseous phase to escape the water, and the waterbody was thus denitrified.

Each microbial online reactor created a microenvironment to cultivate environmental-friendly microbial strains. In the reactor, microorganisms capable of removing nitrogen, curbing sedimentation, and degrading COD, could be produced continuously online. The microbial strains that inhibit nitrogen and sedimentation were selected for continuous production based on the pollution condition of the open channel. These strains ensure the efficiency of pollutant removal.

\subsection{Cultivation of aquatic plants (construction of ecological floating islands)}

Since the open channel has the function of ecological landscape, it is difficult to plant aquatic plants directly in the channel. To solve the problem, ecological floating islands were constructed to plant emergent plants and floating plants. These aquatic plants could absorb water pollutants, creating a certain landscape effect. Considering site survey results and landscape design requirements, a total of $3,000 \mathrm{~m}^{2}$ ecological floating islands were arranged along the open channel. These islands were partly or fully planted with canna, savanna, yellow calamus, and Pontederia cordata. Each island was fixed by DN50 galvanized steel pipes and DN32 heightened casings (Figures 1 and 2).

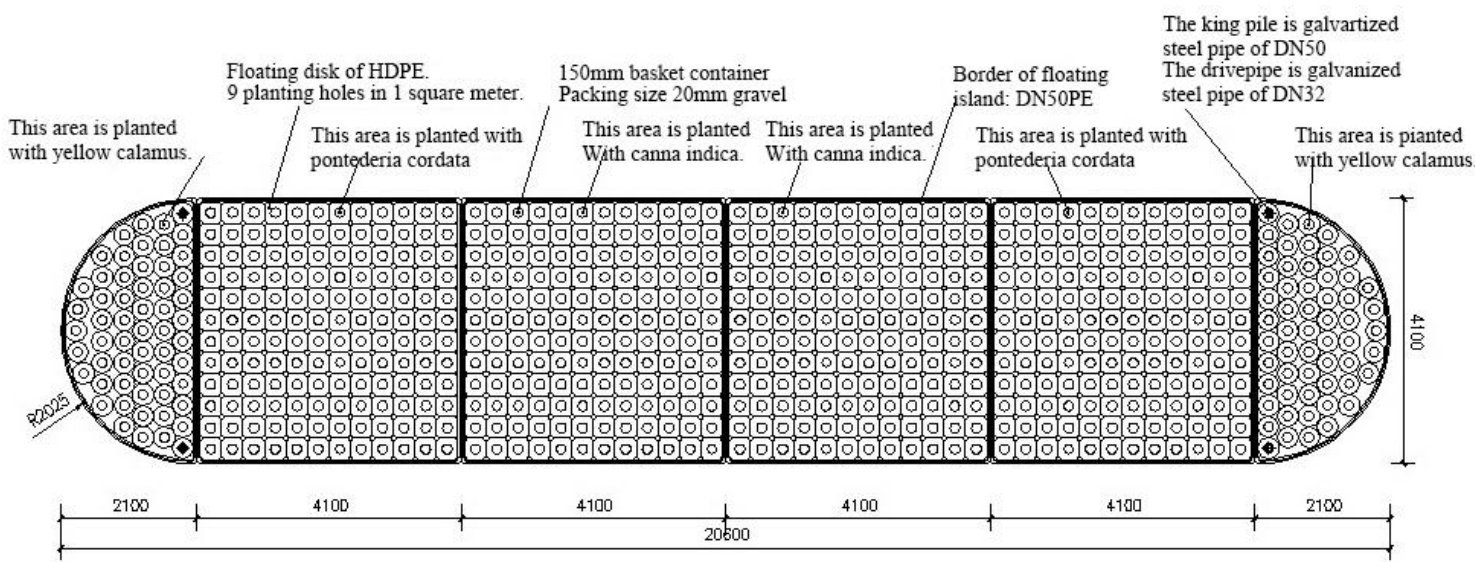

Figure 1. Planar view of an ecological floating island

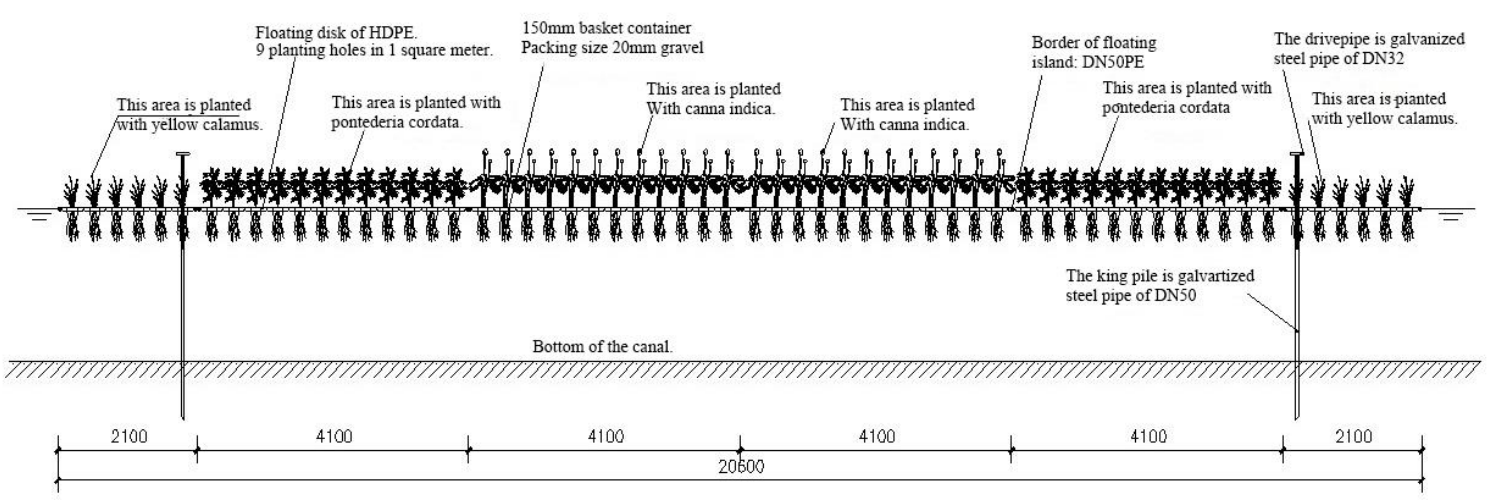

Figure 2. Vertical view of an ecological floating island 


\section{RESULTS AND ANALYSIS}

\subsection{Dynamic evolution of transparency}

As shown in Figure 3, the transparency, a sensory index of water quality, was significantly improved. The overall water transparency increased by an average of $20 \mathrm{~cm}(55 \%)$ from 30 $40 \mathrm{~cm}$ to $50-60 \mathrm{~cm}$. In the first few months, the transparency slightly decreased, as the aeration and reoxygenation system disturbed the water, making particulate matters difficult to sediment. The minimum transparency was observed in January, which has a lot to do with the climate of Wuhan. Under the severe cold climate in January, the plants withered and microorganisms were less active, reducing the remediation effect of the waterbody. After that, the transparency began to slowly rebound to $50-60 \mathrm{~cm}$, indicating that the water quality is significantly improved.

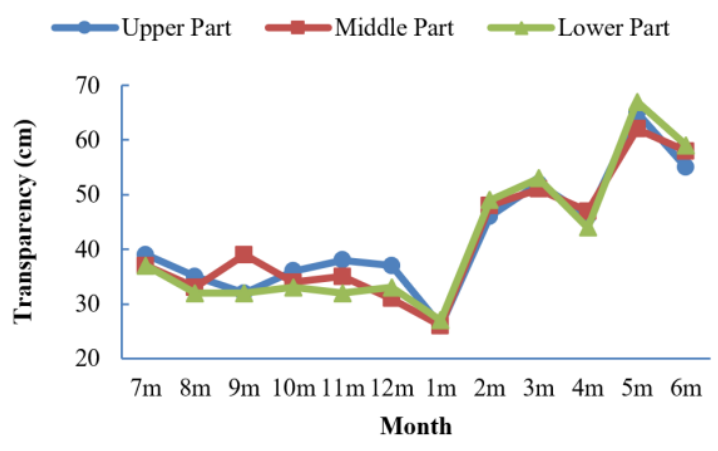

Figure 3. Water transparency in different parts of the open channel

\subsection{Dynamic evolution of DO}

As shown in Figure 4, the DO increased by $180 \%$ from $1.8 \mathrm{mg} / \mathrm{L}$ before treatment to $5.0 \mathrm{mg} / \mathrm{L}$, indicating that the nanoaeration reoxygenation system could greatly improve the DO in the waterbody.

The monitoring started in the early summer. Under the hot weather, the DO was about $4 \mathrm{mg} / \mathrm{L}$. The relatively low DO comes from the following factors: the bottom mud released lots of pollutants, which consumed oxygen faster than the oxygen supply of the waterbody; meanwhile, the waterbody had a low natural DO. The DO dropped to the minimum in January. This is because Wuhan had less sunlight in winter, and the plants entered the withering season; Thus, there were fewer sources of DO, while the BOD in the waterbody remained unchanged. Later, the DO gradually stabilized at above $5.0 \mathrm{mg} / \mathrm{L}$ with the rising temperature, indicating that the waterbody restored much of its self-cleaning ability.

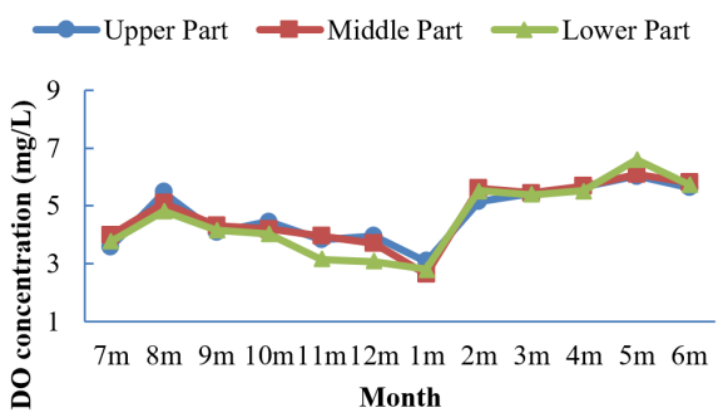

Figure 4. DO in different parts of the open channel

\subsection{Dynamic evolution of COD}

As shown in Figure 5, the COD stabilized between 17 and $27 \mathrm{mg} / \mathrm{L}$ in the remediation period, exhibiting the opposite trend of the DO. The COD of the waterbody gradually increased with the decline of the DO.

The main reason is that the reduction of the DO deactivated aerobic microorganisms (e.g. indigenous aerobic microorganisms), slowing down the degradation of COD. Overall, the COD fell by $31 \%$ on average from $28.98 \mathrm{mg} / \mathrm{L}$ before treatment to below $20 \mathrm{mg} / \mathrm{L}$. The peak COD appeared in January, then gradually stepped down to about $20 \mathrm{mg} / \mathrm{L}$, and tended to be stable. The COD meets the standard for level III surface water in GB3838-2002. The COD trend reflects the climate condition in Wuhan. The remediation effect of COD is much better in summer than in winter. In winter, the plants withered and microorganisms were less active, weakening the remediation effect. In summer, plants grew rapidly under abundant precipitation and microorganisms became highly active, which optimizes the remediation effect.

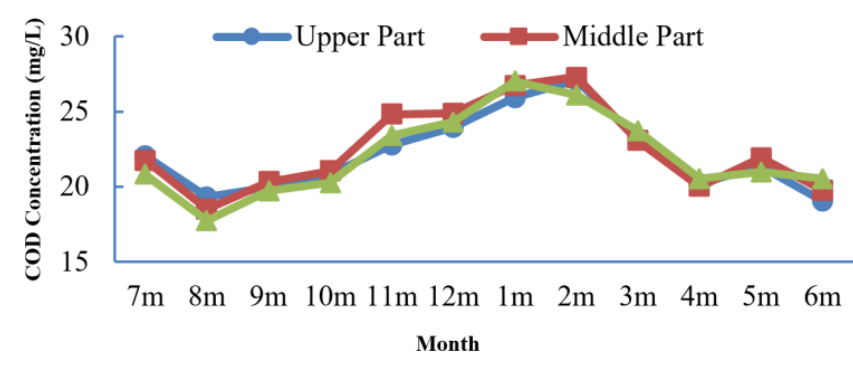

Figure 5. COD in different parts of the open channel

\subsection{Dynamic evolution of $\mathrm{NH}_{3}-\mathrm{N}$}

As shown in Figure 6, the bioremediation reduced the $\mathrm{NH}_{3-}$ $\mathrm{N}$ in the open channel across the abroad. In the early phase, the $\mathrm{NH}_{3}-\mathrm{N}$ decreased steeply to the valley of $0.7 \mathrm{mg} / \mathrm{L}$, but rebounded in September.

The main reason is that, at the start of the treatment, the water pollutants were released fast under the high temperature, surpassing the purification rate; with the elapse of time, beneficial microorganisms continued to grow, and slowly reduced the $\mathrm{NH}_{3}-\mathrm{N}$ in the waterbody. However, the $\mathrm{NH}_{3}-\mathrm{N}$ climbed up to about $7 \mathrm{mg} / \mathrm{L}$, possibly due to the withering of plant roots and deactivation of microorganisms under the low temperature. With the improvement of the aquatic environment, the $\mathrm{NH}_{3}-\mathrm{N}$ exhibited a steady decline and stabilized at about $2 \mathrm{mg} / \mathrm{L}$. This meets the standard for Level V surface water in GB 3838-2002. Through the treatment, about $60 \%$ of all $\mathrm{NH}_{3}-\mathrm{N}$ in the open channel was degraded.

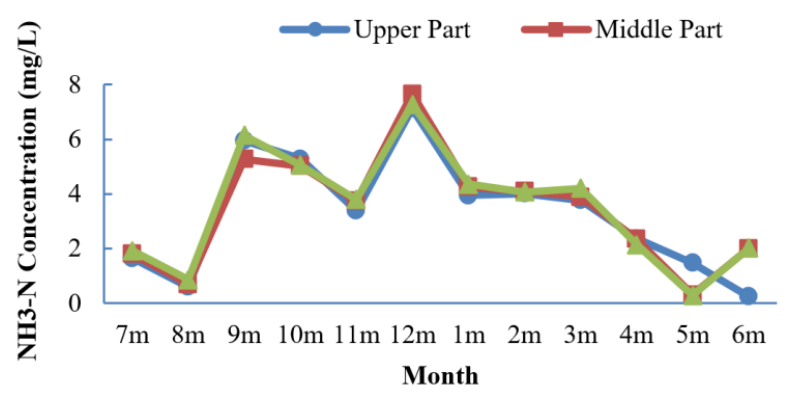

Figure 6. $\mathrm{NH}_{3}-\mathrm{N}$ in different parts of the open channel 


\subsection{Dynamic evolution of TP}

As shown in Figure 7, the TP basically stabilized at about $0.3 \mathrm{mg} / \mathrm{L}$ in the early phase, and rose to the peak of $0.5 \mathrm{mg} / \mathrm{L}$ in January, for TP removal mainly relies on the adsorption and transfer of aquatic plants in biological floating islands. Hence, the TP decline is closely associated with the growth of plants. Under the high temperature in July and August, the plant roots were highly developed, and the plants grew at a rapid rate. The fast-growing plants absorbed the TP in the waterbody quickly, leading to a fast decrease of the TP. When it came to autumn and winter, both microorganisms and plants were less active. The aquatic plants in biological floating islands ceased to grow, and even withered. Thus, the TP in the waterbody increased. Later, with the rise of temperature, the TP steadily decreased to the valley of $0.2 \mathrm{mg} / \mathrm{L}$, which This meets the standard for Level V surface water in GB 3838-2002. Through the treatment, about $55 \%$ of the TP in the open channel was degraded.

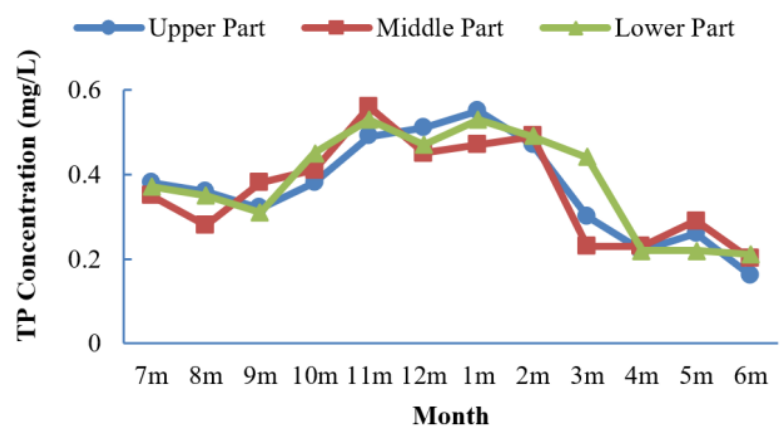

Figure 7. TP in different parts of the open channel

\subsection{Main economic indices}

The treatment cost of the $2.13 \mathrm{~km}$-long open channel (surface area: $23,000 \mathrm{~m}^{2}$ ) totaled RMB 2.35 million yuan, covering the purchase, installation, and debugging fees of biochemical treatment system (including nano-aeration instruments, flexible polymer ecological matrix, ecological stimulators, and online microbial reactors) and $2000 \mathrm{~m}^{2}$ aquatic plants. The operation and maintenance cost includes electricity cost (RMB 168.3yuan/d), labor cost (RMB 240yuan/d), equipment maintenance cost (RMB 180yuan/d). In total, the annual operation and maintenance cost stood at RMB 215,000 yuan, about RMB 9.34 yuan per square meters of the water area in the open channel.

\section{CONCLUSIONS}

Despite successful initial treatment, most black and smelly waterbodies in China are polluted again, returning to the black and smelly state. To realize long-term control of water quality, this paper puts forward an integrated bioremediation method for black and smelly waterbodies, coupling nano-aeration instruments, ecological stimulators, online microbial reactors, and biological floating islands.

Specifically, the nano-aeration and reoxygenation system was used to rapidly boost the DO in the waterbody, activating the indigenous aerobic microbials. The ecological stimulators were adopted for in-situ activation of indigenous waterpurifying microorganisms, while the online microbial reactors were employed to continuously produce environmentalfriendly microorganisms to degrade pollutants. The ecological floating islands were introduced to form rhizobacteria micelles and promote plant growth, speeding up the degradation and transfer of COD, $\mathrm{NH}_{3}-\mathrm{N}$, and TP. These techniques were fully integrated to gradually restore the natural ecology and selfcleaning capacity of the river, kicking off a vicious cycle of the ecosystem in waterbodies.

Experimental results show that the proposed method reduced the $\mathrm{COD}, \mathrm{NH}_{3}-\mathrm{N}$, and $\mathrm{TP}$ in the open channel by $31 \%$, $60 \%$, and $55 \%$, respectively, and improved transparency and DO by $55 \%$, and $180 \%$, respectively. According to the oneyear monitoring data after the treatment, the water quality of the open channel increased from below level V (slightly black and smelly) to level V, and some indices (e.g. DO and TP) even reached the standard for level III surface water. Thus, our method managed to significantly improve the water quality, and eliminated the smell and eutrophication as desired. The research results shed important new light on the treatment of black and smelly waterbodies in urban areas.

\section{ACKNOWLEDGMENT}

The work described in this paper was fully supported by Philosophy and Social Science Research Projects of Hubei Provincial Department of Education (No. 19Q017).

\section{REFERENCES}

[1] Handa, S., Jadhav, R. (2016). Status of heavy metal pollution in Mithi river: Then and now. International Journal of Research in Engineering and Science, 4(1): 62-68.

[2] López-Pacheco, I.Y., Silva-Núñez, A., Salinas-Salazar, C., Arévalo-Gallegos, A., Lizarazo-Holguin, L.A., Barceló, D., Iqbal, H.M.N., Parra-Saldívar, R. (2019). Anthropogenic contaminants of high concern: Existence in water resources and their adverse effects. Science of the Total Environment, 690: 1068-1088. https://doi.org/10.1016/j.scitotenv.2019.07.052

[3] Sposito, J.C., Montagner, C.C., Casado, M., NavarroMartín, L., Solórzano, J.C.J., Piña, B., Grisolia, A.B. (2018). Emerging contaminants in Brazilian rivers: Occurrence and effects on gene expression in zebrafish (Danio rerio) embryos. Chemosphere, 209: 696-704. https://doi.org/10.1016/j.chemosphere.2018.06.046.

[4] Yin, H., Wang, J., Zhang, R., Tang, W. (2019). Performance of physical and chemical methods in the coreduction of internal phosphorus and nitrogen loading from the sediment of a black odorous river. Science of The Total Environment, 663: 68-77. https://doi.org/10.1016/j.scitotenv.2019.01.326.

[5] Wilkinson, J.L., Hooda, P.S., Swinden, J., Barker, J., Barton, S. (2017). Spatial distribution of organic contaminants in three rivers of Southern England bound to suspended particulate material and dissolved in water. Science of the Total Environment, 593: 487-497. https://doi.org/10.1016/j.scitotenv.2017.03.167.

[6] Ahmed, W., Hamilton, K., Toze, S., Cook, S., Page, D. (2019). A review on microbial contaminants in stormwater runoff and outfalls: Potential health risks and mitigation strategies. Science of the Total Environment, 
692:

https://doi.org/10.1016/j.scitotenv.2019.07.055

$1304-1321$.

[7] Yuan, Q. B., Shen, Y., Huang, Y. M., Hu, N. (2018). A comparative study of aeration, biostimulation and bioaugmentation in contaminated urban river purification. Environmental Technology \& Innovation, 11: 276-285. https://doi.org/10.1016/ j.eti. 2018.06.008.

[8] Goher, M.E., Ali, M.H., El-Sayed, S.M. (2019). Heavy metals contents in Nasser Lake and the Nile River, Egypt: An overview. The Egyptian Journal of Aquatic Research, 45: 301-312. https://doi.org/10.1016/j.ejar.2019.12.002

[9] Ministry of Ecology and Environment of the People's Republic of China. (2019). National Urban Blackodorous Waterbodies Governance and Supervision Platform. http://www.hcstzz.com/

[10] Bilal, M., Rasheed, T., Nabeel, F., Iqbal, H.M., Zhao, Y. (2019). Hazardous contaminants in the environment and their laccase-assisted degradation-A review. Journal of environmental management, 234: 253-264. https://doi.org/10.1016/j.jenvman.2019.01.001

[11] Bradley, P.M., Battaglin, W.A., Clark, J.M., Henning, F.P., Hladik, M.L., Iwanowicz, L.R., Journey, C.A., Riley, J.W., Romanok, K.M. (2017). Widespread occurrence and potential for biodegradation of bioactive contaminants in Congaree National Park, USA. Environmental Toxicology and Chemistry, 36(11): 3045-3056. https://doi.org/10.1002/etc.3873.

[12] Castiglioni, S., Davoli, E., Riva, F., Palmiotto, M., Camporini, P., Manenti, A., Zuccato, E. (2018). Mass balance of emerging contaminants in the water cycle of a highly urbanized and industrialized area of Italy. Water Research, 131: 287-298. https://doi.org/10.1016/j.watres.2017.12.047.

[13] Zhao, Y., Yao, R.H., Xu, M., Song, L.L. (2015). Study on the practice and route of combating urban black-andmalodorous water body. Environmental Protection, 43(13): 27-29. https://doi.org/10.14026/j.cnki.02539705.2015.13.005.

[14] Chinyama, A., Ncube, R., Ela, W. (2016). Critical pollution levels in Umguza River, Zimbabwe. Physics and Chemistry of the Earth, Parts A/B/C, 93: 76-83. http://dx.doi.org/10.1016/j.pce.2016.03.008

[15] Garcia, X., Corominas, L., Pargament, D., Acuña, V. (2016). Is river rehabilitation economically viable in water-scarce basins?. Environmental Science \& Policy, 61: $154-164$ http://dx.doi.org/10.1016/j.envsci.2016.04.011

[16] Barletta, M., Lima, A.R., Costa, M.F. (2019). Distribution, sources and consequences of nutrients, persistent organic pollutants, metals and microplastics in South American estuaries. Science of the Total Environment, 651: 1199-1218 https://doi.org/10.1016/j.scitotenv.2018.09.276

[17] Mishra, B.K., Regmi, R.K., Masago, Y., Fukushi, K., Kumar, P., Saraswat, C. (2017). Assessment of Bagmati river pollution in Kathmandu Valley: Scenario-based modeling and analysis for sustainable urban development. Sustainability of Water Quality and Ecology, 9: 67-77. http://dx.doi.org/10.1016/j.swaqe.2017.06.001

[18] Majdi, H.S., Jaafar, M.S., Abed, A.M. (2019). Using $\mathrm{KDF}$ material to improve the performance of multilayers filters in the reduction of chemical and biological pollutants in surface water treatment. South African
Journal of Chemical Engineering, 28: 39-45. https://doi.org/10.1016/j.sajce.2019.01.003

[19] Sun, Y., Iris, K. M., Tsang, D. C., Cao, X., Lin, D., Wang, L., Graham, N.J.D., Alessi, D.S., Komárek, M., Ok, Y.S., Feng, Y., Li, X. (2019). Multifunctional iron-biochar composites for the removal of potentially toxic elements, inherent cations, and hetero-chloride from hydraulic fracturing wastewater. Environment International, 124: 521-532. https://doi.org/10.1016/j.envint.2019.01.047.

[20] Inostroza, P.A., Massei, R., Wild, R., Krauss, M., Brack, W. (2017). Chemical activity and distribution of emerging pollutants: Insights from a multi-compartment analysis of a freshwater system. Environmental Pollution, 231: 339-347. https://doi.org/10.1016/j.envpol.2017.08.015.

[21] Viganò, L., Stefani, F., Casatta, N., Mascolo, G., Murgolo, S., Roscioli, C., Zonta, R. (2019). Contamination levels and spatial distribution in the lagoons of the Po river delta: Are chemicals exerting toxic effects?. Estuarine, Coastal and Shelf Science, 231: 106467. https://doi.org/10.1016/j.ecss.2019.106467

[22] Dsikowitzky, L., Van der Wulp, S.A., Ariyani, F., Hesse, K.J., Damar, A., Schwarzbauer, J. (2018). Transport of pollution from the megacity Jakarta into the ocean: Insights from organic pollutant mass fluxes along the Ciliwung River. Estuarine, Coastal and Shelf Science, 215:

219-228. https://doi.org/10.1016/j.ecss.2018.10.017

[23] Zhu, L., Li, X., Zhang, C., Duan, Z. (2017). Pollutants' release, redistribution and remediation of black smelly river sediment based on re-suspension and deep aeration of sediment. International Journal of Environmental Research and Public Health, 14(4): 374-383. https://doi.org/10. 3390/ijerph14040374.

[24] Maroušek, J., Stehel, V., Vochozka, M., Kolář, L., Maroušková, A., Strunecký, O., Peterka, J., Kopecký, M., Shreedhar, S. (2019). Ferrous sludge from water clarification: Changes in waste management practices advisable. Journal of Cleaner Production, 218: 459-464. https://doi.org/10.1016/j.jclepro.2019.02.037

[25] Lee, I., Hwang, H., Lee, J., Yu, N., Yun, J., Kim, H. (2017). Modeling approach to evaluation of environmental impacts on river water quality: A case study with Galing River, Kuantan, Pahang, Malaysia. Ecological Modelling, 353: 167-173. http://dx.doi.org/10.1016/j.ecolmodel.2017.01.021

[26] Mandaric, L., Mor, J.R., Sabater, S., Petrovic, M. (2018). Impact of urban chemical pollution on water quality in small, rural and effluent-dominated Mediterranean streams and rivers. Science of the Total Environment, 613: http://dx.doi.org/10.1016/j.scitotenv.2017.09.128

[27] Whitehead, P., Bussi, G., Hossain, M.A., Dolk, M., Das, P., Comber, S., Peters, R., Charles, K.J., Hope, R., Hossain, M.S. (2018). Restoring water quality in the polluted Turag-Tongi-Balu river system, Dhaka: Modelling nutrient and total coliform intervention strategies. Science of the Total Environment, 631: 223232. https://doi.org/10.1016/j.scitotenv.2018.03.038

[28] Truttmann, L., Su, Y., Lee, S., Burkhardt, M., Brynjólfsson, S., Chong, T.H., Wu, B. (2020). Gravitydriven membrane (GDM) filtration of algae-polluted surface water. Journal of Water Process Engineering, 36: 101257. https://doi.org/10.1016/j.jwpe.2020.101257 
[29] Liu, M., Ran, Y., Peng, X., Zhu, Z., Liang, J., Ai, H., Li, H., He, Q. (2019). Sustainable modulation of anaerobic malodorous black water: The interactive effect of oxygen-loaded porous material and submerged macrophyte. Water Research, 160: 70-80. https://doi.org/10.1016/j.watres.2019.05.045

[30] Yang, Z., He, L.S., Jiang, D.L., Yuan, Z., Liu, X.N. (2017). Research progress of aeration purification technology for black and odorous water body. Technology of Water Treatment, 43(10): 49-53. https://doi.org/10.16796/j.cnki.1000-3770.2017.10.013

[31] Pan, M., Zhao, J., Zhen, S., Heng, S., Wu, J. (2016). Effects of the combination of aeration and biofilm technology on transformation of nitrogen in black-odor river. Water Science and Technology, 74(3): 655-662. https://doi.org/10.2166/wst.2016.212

[32] Lu, B., Xu, Z., Li, J., Chai, X. (2018). Removal of water nutrients by different aquatic plant species: An alternative way to remediate polluted rural rivers. Ecological Engineering, 110: 18-26. https://doi.org/10.1016/j.ecoleng.2017.09.016

[33] Saeed, T., Paul, B., Afrin, R., Al-Muyeed, A., Sun, G. (2016). Floating constructed wetland for the treatment of polluted river water: A pilot scale study on seasonal variation and shock load. Chemical Engineering Journal, 287: 62-73. https://doi.org/10.1016/j.cej.2015. 10.118.

[34] Wagner, I., Zalewski, M. (2016). Temporal changes in the abiotic/biotic drivers of selfpurification in a temperate river. Ecological Engineering, 94: 275-285. http://dx.doi.org/10.1016/j.ecoleng.2016.05.073

[35] Al-Mailem, D.M., Al-Deieg, M., Eliyas, M., Radwan, S.S. (2017). Biostimulation of indigenous microorganisms for bioremediation of oily hypersaline microcosms from the Arabian Gulf Kuwaiti coasts. Journal of Environmental Management, 193: 576-583. http://dx.doi.org/10.1016/j.jenvman.2017.02.054

[36] Simpanen, S., Dahl, M., Gerlach, M., Mikkonen, A., Malk, V., Mikola, J., Romantschuk, M. (2016). Biostimulation proved to be the most efficient method in the comparison of in situ soil remediation treatments after a simulated oil spill accident. Environmental Science and Pollution Research, 23(24): 25024-25038. https://doi.org/10.1007/s11356-016-7606-0

[37] Hasan, H.A., Muhammad, M.H. (2020). A review of biological drinking water treatment technologies for contaminants removal from polluted water resources. Journal of Water Process Engineering, 33: 101035. https://doi.org/10.1016/j.jwpe.2019.101035

[38] Chen, Q., Guo, B., Zhao, C., Zhang, J. (2019). A comprehensive ecological management approach for northern mountain rivers in China. Chemosphere, 234: $25-33$. https://doi.org/10.1016/j.chemosphere.2019.06.042

[39] de Matos, A.T., de Matos, M.P., de Almeida Costa, R., von Sperling, M. (2018). Influence of the geometric configuration of unplanted horizontal subsurface flow constructed wetlands in the adjustment of parameters of organic matter decay models. Journal of Water Process Engineering, 22: 123-130 https://doi.org/10.1016/j.jwpe.2018.01.009

[40] Lv, P.Y., Luo, J.X., Han, Z.F., Huang, Z.B. (2017). Application and research progress of biofilm technology in polluted river in-situ bioremediation. Technology of
Water Treatment, 43: 7-11. https://doi.org/10.16796/j.cnki.1000-3770.2017.11.001.

[41] Saeed, T., Majed, N., Khan, T., Mallika, H. (2019). Twostage constructed wetland systems for polluted surface water treatment. Journal of Environmental Management, 249: 109379. https://doi.org/10.1016/j.jenvman.2019.109379

[42] Lucke, T., Walker, C., Beecham, S. (2019). Experimental designs of field-based constructed floating wetland studies: A review. Science of the Total Environment, 660: 199-208. https://doi.org/10.1016/j.scitotenv.2019.01.018

[43] Masi, F., Rizzo, A., Bresciani, R., Conte, G. (2017). Constructed wetlands for combined sewer overflow treatment: ecosystem services at Gorla Maggiore, Italy. Ecological Engineering, 98: 427-438. http://dx.doi.org/10.1016/j.ecoleng.2016.03.043

[44] Ávila, C., Pelissari, C., Sezerino, P.H., Sgroi, M., Roccaro, P., García, J. (2017). Enhancement of total nitrogen removal through effluent recirculation and fate of PPCPs in a hybrid constructed wetland system treating urban wastewater. Science of the Total Environment, 584: 414-425. http://dx.doi.org/10.1016/j.scitotenv.2017.01.024

[45] Nguyen, X.C., Nguyen, D.D., Tran, Q.B., Nguyen, T.H., Tran, T.A., Tran, T.P., Balasubramani, R. (2020). Twostep system consisting of novel vertical flow and free water surface constructed wetland for effective sewage treatment and reuse. Bioresource Technology, 123095. https://doi.org/10.1016/j.biortech.2020.123095

[46] Olguín, E.J., Sánchez-Galván, G., Melo, F.J., Hernández, V.J., González-Portela, R.E. (2017). Long-term assessment at field scale of Floating Treatment Wetlands for improvement of water quality and provision of ecosystem services in a eutrophic urban pond. Science of the Total Environment, 584: 561-571. http://dx.doi.org/10.1016/j.scitotenv.2017.01.072

[47] Saggaï, M.M., Aïnouche, A., Nelson, M., Cattin, F., El Amrani, A. (2017). Long-term investigation of constructed wetland wastewater treatment and reuse: Selection of adapted plant species for metaremediation. Journal of Environmental Management, 201: 120-128. http://dx.doi.org/10.1016/j.jenvman.2017.06.040

[48] Panfili, I., Bartucca, M.L., Ballerini, E., Del Buono, D. (2017). Combination of aquatic species and safeners improves the remediation of copper polluted water. Science of the Total Environment, 601: 1263-1270. http://dx.doi.org/10.1016/j.scitotenv.2017.06.003

[49] Urakawa, H., Bernhard, A.E. (2017). Wetland management using microbial indicators. Ecological Engineering, $\quad$ 108: 456-476. http://dx.doi.org/10.1016/j.ecoleng.2017.07.022

[50] Huang, B.P., Yang, S.P., Li, X.H. (2016). River ecological restoration case of Singapore-Nanjing ecological science and technology island. Water \& Wastewater Engineering, 42(S1): 75-78. https://doi.org/10.13789/j.cnki.wwe1964.2016.0344

[51] Xu, J.B. (2018). Practical study on comprehensive control of black-odorous river in Kunshan. China Municipal Engineering, 198(3): 54-57, 118-119. https://doi.org/10.3969/j.issn.1004-4655.2018.03.017

[52] Zheng, J.L., Pan, H.Z., Zhuang, H.Q. (2018). Treatment and ecological restoration of urban black-odorous river in Changzhou Zaogang River. China Water \& Wastewater, 34(22): 90-95. 
[53] Meyer, A.M., Klein, C., Fünfrocken, E., Kautenburger, R., Beck, H.P. (2019). Real-time monitoring of water quality to identify pollution pathways in small and middle scale rivers. Science of the Total Environment, 651: 2323-2333.

https://doi.org/10.1016/j.scitotenv.2018.10.069
[54] Warner, W., Licha, T., Nödler, K. (2019). Qualitative and quantitative use of micropollutants as source and process indicators. A review. Science of the Total Environment, $\quad 686$ :

75-89. 